\title{
> Sobre lampejos em tempos de chumbo, ou, por uma comunidade de vaga-lumes, ou, o que pode a arte?
}

> About glimpses in ages of lead or for a community of fireflies or what can art do?

por Antônio Carlos Sobrinho

Centro Universitário Jorge Amado (Unijorge).

E-mail: tonysobr@hotmail.com. ORCID: 0000-0003-2926-2779.

\section{Resumo}

Esta não é uma escrita que procura falar sobre textos artísticos em específico, no sentido de interpretá-los. Ao invés disso, ela se deixa atravessar por aquilo que, na arte, é força de. Ou, força para. Noutras palavras, deseja o estar com, ou melhor, o ser com. Trata-se de recolher abraços de artistas diversxs, de épocas distintas e de linguagens várias, não como uma energia apaziguadora, mas como aumento da potência de agir. Abraços vagalumes. Neste caminho, intenta-se uma reflexão sobre como a arte pode ser força para a não capitulação dos sujeitos, ainda que inseridos em contextos (macro e micro) políticos em que quase tudo ganha a cor e o peso do chumbo. Assim como o Brasil de 2019.

Palavras-chave: Vaga-lumes. Arte. Resistência.

\begin{abstract}
This is not a writing that seeks to talk about specific artistic texts towards interpretion. Instead, it allows itself to be crossed by what in art is the "strength of". Or "strength to". In other words, it desires to be with. It is about collecting hugs from different artists, from different eras and from different languages, not as a peacemaking energy but as an increase in the power of acting. Fireflies hugs. In this way, intents to a reflection on how art can be strength for the non-surrendering of the subjects, although inserted in (macro and micro) politics contexts in which almost everything gets the color and the weight of the lead just like Brazil in 2019.
\end{abstract}

Keywords: Fireflies. Art. Resistence. 


\title{
1. Ser força
}

$\mathrm{Na}$ segunda carta que escreve a Luciana di Leone, sua amiga e interlocutora, Diana Klinger registra algum desencanto em relação à experiência da vida contemporânea ${ }^{1}$. Afirma que suas idas à biblioteca para leituras e pesquisas, bem como o esboço do livro que então escrevia, não eram mais do que uma tentativa de entrar em contato com a força que há no texto literário. Em "aprender a sobreviver", que vem a ser o título desta carta, Klinger escreve:

\begin{abstract}
Eu passei os dias naquela biblioteca, esboçando esse livro para dizer apenas que eu queria e precisava recuperar uma força que há na literatura e que a burocratização da vida acadêmica e a banalização da narrativa contemporânea tinham me feito esquecer. Eu queria acreditar naquela força, porque as coisas, todas as coisas, foram ficando piores. Se viver é preciso, temos que aprender a sobreviver. Aprender a se reencantar por alguma coisa, a acreditar em alguma prática².
\end{abstract}

Embora não seja de meu gosto iniciar textos com citações, julguei adequado fazê-lo desta vez. Não sei se Klinger e eu nos reportamos exatamente às mesmas razões, mas as coisas, todas as coisas, estão, de fato, ficando piores. Nesse cenário, assim como ela, é na possibilidade de a arte ser força para mim, para nós, que deposito meu movimento de procura, minha linha de fuga.

Não tenho o desejo nem o objetivo de comentar a fundo os poemas, as imagens, as canções que virão nas páginas seguintes. Não almejo nenhum exercício de interpretação, de busca por um sentido. O que pretendo é de outra ordem: quero o encontro com aquilo que tais textos mobilizam de afetos, o enlace com o que restauram de força. Procedimento: (re)visitar estxs ${ }^{3}$ artistas, ouvir carinhosamente o que têm a me dizer, recolher os seus abraços, compartilhá-los

\footnotetext{
${ }^{1}$ Diana Klinger, Literatura e ética: da forma para a força, 2014.

${ }^{2}$ Ibidem, p. 143.

${ }^{3}$ Opto, ao longo de todo este ensaio, pela utilização do símbolo $\mathrm{x}$ ao invés de desinências responsáveis por flexionar os nomes em função de marcações binárias de gênero. Entendo que esta ainda não é, e talvez não venha a ser, prática corrente na escrita acadêmica, podendo ocasionar alguma incompreensão. No entanto, escrever deste modo se trata mesmo de um gesto político. Significa pensar sobre a língua (e sobre a linguagem) de maneira a não se deixar seduzir pelo olhar de Medusa das formas já fixadas, com seus perigos e silenciamentos. Assim, na medida do possível, pretendo alcançar modos de dizer que se esforcem em não operar por exclusões e violências.
} 
com quantxs eu puder. Sigo Klinger que, na esteira de Spinoza, abdica de pensar a produção artística como objeto para percebê-la como ato, perspectiva a partir da qual "[...] ela só vai ter um sentido (para mim) quando produzir reverberações (em mim), e desse encontro entre mim e a obra resultar um aumento de (minha) 'potência de existir"'4.

"Em vez de uma hermenêutica, precisamos de uma erótica da arte", já advertiu Susan Sontag 5 . O contato pele-a-pele, cheiro-a-cheiro, entre o corpo-arte e este corpo que sou eu não solicita um exercício de dissecação do que é víscera, do que está dentro, supostamente escondido. Antes, reclama pela dinâmica própria aos corpos que se encontram, que se tocam, que se atravessam. Pede pela força que há neste ato de estar com.

Sim, uma erótica: este é um texto de encontros.

A primeira versão deste ensaio, originalmente pensado com abordagem reduzida às produções literárias, foi apresentada, na tarde do dia 01 de novembro de 2018, ao público do VI Simpósio Internacional Horizontes Humanos: narrativas, formações e práticas de resistência em tempos de incerteza e intolerância, realizado na Universidade de Brasília (UnB). Ou seja, logo após o resultado das eleições que encaminharam Jair Messias Bolsonaro à presidência do Brasil. Naquela ocasião, pensei em escrevê-lo ao mesmo tempo como clínica de mim e como força para quem me ouvisse, tentando aproximá-lo ao máximo de uma perspectiva éticoestético-clínico-política, tal como propõe Suely Rolnik como forma de insurreição às micropolíticas reativas que organizam os lugares contemporâneos de hegemonia 6 . Retomo-o agora, quando se completam os cem primeiros dias de seu governo. A mesma sensação de que tudo tende ao pior que eu tinha lá, ainda tenho agora. E, assim como o fiz em Brasília, procuro na arte formas de reverter esta condição de derrota, cuja decorrente apatia serve apenas aos interesses do

\footnotetext{
${ }^{4}$ Ibidem, p. 56.

${ }^{5}$ Susan Sontag, Contra a interpretação (1964),1987, p. 23.

${ }^{6}$ Suely Rolnik, O inconsciente colonial-capitalístico, 2018.
} 
poder instituído. Busco por encontros cuja potência de invenção, no dizer de Rolnik,

[...] possa vir a ter força suficiente para conter o poder das forças que prevalecem em outras constelações - aquelas que se compõem de corpos que tentam cafetinar a pulsão vital alheia ou que se entregam à sua cafetinagem. Com essas sinergias, abrem-se caminhos para desviar tal potência de seu destino destruidor? ${ }^{7}$.

Afinal, as coisas estão mesmo ficando piores e, de fato, é necessário (re)aprender a sobreviver. É, portanto, no desejo de que os encontros que este texto reverbera sejam forças fortes para mim e para quem o leia que eu retomo sua escrita nesta nova versão.

\section{Uma coisa é um país, outra...}

Será que nunca faremos senão confirmar a incompetência da América católica que sempre precisará de ridículos tiranos?

Caetano Veloso, Podres Poderes.

Domingo, 28 de outubro de 2018.

Esta é mais uma entre as diversas tentativas de começo para este texto. Sem dúvida, é a mais complicada; a mais difícil de todas. Há qualquer coisa de amargo em registrar essa data; qualquer coisa de peso em cada palavra digitada, qualquer coisa de dor agulhando fina, finíssima, sob as unhas dos dedos.

A noite avança madrugada adentro de segunda, tinge de sombra e de chumbo o amanhecer.

${ }^{7}$ Ibidem, p. 39. 
Somos, neste momento, um país de cinquenta e sete milhões, setecentos e noventa e sete mil, oitocentos e quarenta e sete homens-noite ${ }^{8}$. Segundo dados oficiais divulgados pelo $\mathrm{TSE}^{9}$, quase sessenta milhões de pessoas conduziram à presidência um discurso de violação dos direitos humanos; um discurso laudatório da ditadura militar e de seus torturadores e assassinos; um discurso promotor da mais absoluta truculência.

"Uma coisa é um país, outra o aviltamento" - dizia, certeiro, o poeta Affonso Romano de Sant'Anna, quando se perguntava, em meio a tantos generais, "Que país é este?"10.

Somos, hoje, e novamente, um aviltamento. Um aviltamento monstruoso, no pior sentido que esta palavra admite. Um aviltamento de cinquenta e sete milhões, setecentas e noventa e sete mil, oitocentas e quarenta e sete identidades predatórias, para fazer uso da formulação conceitual de Arjun Appadurai ${ }^{11}$.

Os predadores, instalados nos lugares de hegemonia a partir dos quais projetam uma nação sem fraturas, homogeneizada em acordo a seus padrões, veem no pequeno número, as diversas minorias, a presença terrível de um perigo: a diferença que se desvia do modelo instituído; o corpo não docilizado, que escapa de qualquer controle, que produz tensões e que aponta para outros modos de existir. O pequeno número, cuja simples existência desorganiza os discursos de unificação nacional, desestabiliza a imagem de um povo coeso, trinca os espelhos dispostos e fissura a universalidade da lógica do poder. Este, o pequeno

\footnotetext{
${ }^{8}$ Neste caso, como também em relação à palavra "predadores", utilizada um pouco mais à frente, opto pela marcação do gênero, uma vez que a composição majoritária dxs eleitorxs de Jair Messias Bolsonaro é constituída por homens. Para além disso, a expressão "homens-noite" procura igualmente problematizar uma forma específica de fazer política, sobretudo conduzida a partir de um masculino, a qual se baseia nos usos da força, da truculência e da intimidação. Por último, "homens-noite", bem como "predadores", se relacionam ao lugar de hegemonia ainda ocupado pelos homens em nossa sociedade - o que não apenas justifica a utilização do signo "homem", no primeiro caso, e da flexão de gênero, no segundo, como as solicita, tendo em vista a necessidade de melhor definir os lugares dos quais emanam processos de opressão e assujeitamento.

${ }^{9}$ Os números oficiais referentes às eleições do ano de 2018 podem ser consultados no seguinte endereço: http://divulga.tse.jus.br/oficial/index.html

${ }^{10}$ Affonso Romano de Sant'Anna, Que país é este? (1980), 1990, p. 1

${ }^{11}$ Arjun Appadurai, o medo ao pequeno número, 2009.
} 
número, a pretexto da preservação da pátria, da família, dos valores morais, da fé cristã, da propriedade privada - ou qualquer outra abstração discursiva que procure legitimar processos de violência - precisa ser rebaixado, monitorado, disciplinado e, quando não de todo submetido, preso, silenciado, exterminado. "As minorias devem se calar diante da maioria", disse, uma vez, o então deputado federal Jair Messias Bolsonaro, hoje eleito presidente do Brasil por cinquenta e sete milhões, setecentos e noventa e sete mil, oitocentos e quarenta e sete votos predatórios. Ou, no mínimo, já que nem todo mundo gosta de sujar as próprias mãos, votos cúmplices e permissivos de uma caçada predatória já em funcionamento.

Somos, hoje, e novamente, um aviltamento.

O número assusta, causa espanto, apreensão. Sei que o Brasil não é, nunca foi, correspondente à harmonia edulcorada por nosso mito fundador. Marilena Chauí já discutiu a nossa mitologia fundacional, expondo o quanto ela precisa ritualmente se repetir para que não percebamos o seu contrário, que é o nosso real: um modus operandi que se dá por uma violência e um autoritarismo estruturantes do cotidiano brasileiro, nos configurando, microfisicamente, como sociedade ${ }^{12}$. Mas, muito antes de lê-la, eu já havia seguido e finalizado a leitura de Affonso Romano de Sant'Anna:

Há 500 anos caçamos índios e operários,

há 500 anos queimamos árvores e hereges,

há 500 anos estupramos livros e mulheres,

há 500 anos sugamos negras e aluguéis.

$[\ldots]$

País:

loucura de quantos generais a cavalo

escalpelando índios nos murais

queimando caravelas e livros

${ }^{12}$ Marilena Chauí, Brasil, mito fundador e sociedade autoritária (2000), 2010. 


\author{
- nas fogueiras e cais \\ homens gordos melosos sorrisos comensais \\ politicando subúrbios e arando votos \\ e benesses nos palanques oficiais ${ }^{13}$
}

Não é tanto o Brasil sem máscaras que me impacta, este é conhecido de outro tempo, este é um velho inimigo. Mas, a intensidade com que se apresenta o desejo de uma guerra santa. A quantidade de assentimentos à bravata de expurgar os vermelhos. A aderência massiva a um tom bélico reativo às políticas de inclusão de minorias e aos ativismos, cujas ações de tensionamento correm o risco de serem tipificadas como atos de terrorismo. O que me espanta é o número. Ele, sim, me abala. Convenhamos, 55,1\% diz pouco. Indica apenas uma maioria difusa, um tanto quanto abstrata. Cinquenta e sete milhões, setecentos e noventa e sete mil, oitocentos e quarenta e sete, por sua vez, traduz em concreto a quantidade de homens-noite. "Por isso, cuidado meu bem, / há perigo na esquina / eles venceram / e o sinal / está fechado para nós"14. Os predadores estão à solta. E são muitos.

Félix Guattari, ao invés de visualizar, nas décadas finais do século XX, a superação das estruturas fascistas, supostamente derrotadas em virtude da queda dos regimes totalitários europeus, identifica nelas o exato oposto: uma potencialização micropolítica ${ }^{15}$. Isto significa perceber uma dinâmica social eivada de pequenos fascismos, imperceptíveis se nosso olhar mirar apenas a macropolítica. Tratam-se de determinadas estratégias de captura e de controle que se exercem, nas mais corriqueiras tramas cotidianas, por intermédio de insuspeitos cidadãos autoproclamados "de bem" - predadores, sabemos, nunca se afirmam como tais: são lobos em pele de cordeiro.

\footnotetext{
${ }^{13}$ Affonso Romano de Sant'Anna, Op. Cit.., 1990, p. 2 a 6.

${ }^{14}$ Belchior, Como nossos pais, 1976.

${ }^{15}$ Félix Guattari, Revolução molecular: pulsações políticas do desejo (1981), 1985.
} 
O Brasil, que apresenta casos de censura no campo artístico, além de constrangimentos a artistas que promovem tensionamentos no palco onde se apresentam e se posicionam; o Brasil, que pretende monitorar e silenciar professorxs e estudantes de todos os níveis, além de retirar das universidades o direito à autonomia no tocante a posicionamentos políticos; o Brasil, que aplaude discursos de ódio e de violação da dignidade do outro; o Brasil, que extermina a população LGBTQI+, a juventude negra, os povos indígenas e militantes sociais; o Brasil, que acredita na arma como elemento pacificador; o Brasil, que pretende caçar e varrer pensadorxs de esquerda; o Brasil cujxs parlamentares são ameaçadxs, precisando abdicar do cargo para o qual foram eleitxs e sair do país para que resguardem as próprias vidas; o Brasil, que celebra nomes de torturadores e de assassinos; o Brasil que recomenda às suas forças armadas a comemoração pelo golpe de 1964; o Brasil, com seus quase 60 milhões de votos em Bolsonaro, é um triste exemplo desse cenário.

(Ao escrever o último parágrafo, não me sinto tão distante de Gonzaguinha, que, em 1980, cantava: "memória de um tempo / onde lutar por seu direito / é um defeito / que mata"16).

Para dizer com Clarice: somos hoje, e novamente, um país repleto de "sonsos essenciais"17. Mais precisamente, cinquenta e sete milhões, setecentos e noventa e sete mil, oitocentos e quarenta e sete sonsos essenciais, essa condição de gente que, a pretexto de salvaguardar seu modo de vida em relação aos abalos provocados pela existência do outro, abraça uma justiça que não é justiça e fecha olhos para os corpos que se amontoam à sua volta.

É certo que o presidente eleito, em suas primeiras entrevistas, garantiu governar em respeito absoluto à Constituição. E é certo, também, que, de antemão, todo mundo merece o benefício da dúvida. No entanto, seriam suas promessas de agora suficientes para nos fazer esquecer os 29 anos anteriores de

\footnotetext{
${ }^{16}$ Gonzaguinha, Pequena memória para um tempo sem memória, 1980.

${ }^{17}$ Clarice Lispector, Mineirinho (1962), 2016.
} 
sua atuação política? Algumas atitudes dele e de sua base de apoio neste pouco tempo de governo alertam que não: ameaças ao Supremo Tribunal Federal e ao Congresso Nacional; ausência completa de diálogo com deputadxs e senadorxs, bem como com a sociedade civil; truculência junto à imprensa e à esquerda; intimidação a professorxs, legitimação discursiva da violência.

O que virá depois? Não sei se o slogan "ame-o ou deixe-o" retornará, mas talvez precisemos atualizar aquela letra do Ivan Lins e do Vitor Martins, posteriormente interpretada de forma brilhante por Elis Regina, que dizia de tempos já idos: "Perdoem a cara amarrada / perdoem a falta de abraço / perdoem a falta de espaço / os dias são assim"18.

\title{
3. Abraços vaga-lumes
}

\author{
Tudo é incerto ou falso ou violento: brilha. \\ Tudo é terror vaidade orgulho teimosia: brilha. \\ Tudo é pensamento realidade sensação saber: brilha. \\ Tudo é treva ou claridade contra a mesma treva: brilha. \\ Desde sempre ou desde nunca para sempre ou não: brilha. \\ Uma pequenina luz bruxuleante e muda \\ Como a exactidão como a firmeza \\ como a justiça. \\ Apenas como elas. \\ Mas brilha. \\ Não na distância. Aqui \\ no meio de nós. \\ Brilha. \\ Jorge de Sena, Uma pequenina luz.
}

Mas... o que a arte tem a ver com tudo isso? Ou melhor, o que pode a arte contra tudo isso?

Nos idos não tão distantes de 1940, o avanço do nazi-fascismo e o drama da Segunda Guerra Mundial, um tempo de incertezas e de intolerâncias que

${ }^{18}$ Ivan Lins e Vitor Martins, Aos nossos filhos, 1978. 
guarda certa semelhança com o nosso, solicitaram ao poeta mineiro Carlos Drummond de Andrade os seguintes versos:
A noite caiu. Tremenda, sem esperança... Os suspiros acusam a presença negra que paralisa os guerreiros. E o amor não abre caminho na noite. A noite é mortal, completa, sem reticências, a noite dissolve os homens, diz que é inútil sofrer, A noite dissolve as pátrias, apagou os almirantes cintilantes! nas suas fardas. A noite anoiteceu tudo.. O mundo não tem remédio ${ }^{19} \ldots$

A noite dissolve os homens. Sem muitos espaços de respiro, a vida se assemelha cada vez mais à contingência de um quarto sem portas ou janelas, ausência completa de saídas: apenas entradas. O primeiro movimento do poema, marcado por um tom crepuscular, se desdobra em imagens de um absoluto desamparo: a noite, com o seu poder de morte, é sem jeito. Em face dela, ou sob o seu domínio, nem mesmo o amor, esta força de vida, encontra um caminho possível. Tudo, já anoitecido pela noite, tende ao fim. $\mathrm{O}$ último verso deste arco inicial é duro, impactante. Mergulhado no noturno mais escuro, o poeta sentencia: "os suicidas tinham razão"20.

Neste ponto, impossível não recuperar a memória de Walter Benjamin. Pouco antes de seu gesto maior de amor à vida, o suicídio, cometido em 1940 ante a possibilidade de prisão pelas tropas nazistas e encaminhamento para os campos de concentração e de morte, ele alertava para o fato de que nem mesmo xs mortxs estariam em segurança caso o inimigo vencesse. E complementava: "e esse inimigo não tem cessado de vencer"21.

\footnotetext{
${ }^{19}$ Carlos Drummond de Andrade, A noite dissolve os homens (1940), 2012, p. 61.

${ }^{20}$ Ibidem, p. 61.

${ }^{21}$ Walter Benjamin, Sobre o conceito da história (1940), 2012, p. 244.
} 
De fato, não tem cessado de vencer. Estamos novamente sob o domínio de um céu noturno sem estrelas e de homens-noite que colocam em risco até mesmo xs nossxs mortxs - nossxs desaparecidxs políticxs estão sendo assassinadxs pela segunda ou terceira vez. E pela segunda ou terceira vez, as mães e os pais de nossxs desaparecidxs políticxs não têm o direito de enterrá-lxs.

Sintomaticamente, a memória foi em busca do poeta mineiro. No seu abraço de artista, encontro não apenas a partilha de um sentimento em comum, o desamparo diante de um fantasma que retorna, mas, sobretudo, uma potência de agir. É que "a esperança equilibrista / sabe que o show de todo artista / tem de continuar"22. Apesar de os suicidas terem razão, o eu-lírico não concede sua morte à máquina-noite. No verso seguinte, que inicia uma atitude de enfrentamento à prevalência noturna, Drummond divisa uma aurora que, mesmo tímida, virá, embora não saiba precisamente quando. A este futuro, imagem da qual se projeta o signo de uma esperança ativa, o poeta atribui uma capacidade de instaurar manhãs responsáveis por decompor todo e qualquer traço de noite:

\author{
Havemos de amanhecer. O mundo \\ se tinge com as tintas da antemanhã \\ e o sangue que escorre é doce, de tão necessário \\ para colorir tuas pálidas faces, aurora ${ }^{23}$.
}

A um hoje de sombras, noite e chumbo, é contraposta a certeza de um amanhã redentor que anima a luta contra o presente, que instaura resistências. $\mathrm{X}$ artista trabalha pela vida, mesmo quando a lei de seu tempo a persegue, a limita e a procura extinguir. A arte é uma força em demanda constante pelo estar aqui. Nesse sentido, por intermédio da arte, é possível que se elabore um dizer sobre tudo o que, fora dela, se procura conter, reprimir, apagar. Para Jacques Derrida,

\footnotetext{
22 João Bosco e Aldir Blanc, O bêbado e a equilibrista, 1979.

${ }^{23}$ Carlos Drummond de Andrade, Op. Cit., p. 62.
} 
o espaço da literatura não é somente o de uma ficção instituída, mas também o de uma instituição fictícia, a qual, em princípio, permite dizer tudo. Dizer tudo é, sem dúvida, reunir, por meio da tradução, todas as figuras umas nas outras, totalizar formalizando; mas dizer tudo é também transpor os interditos. É liberar-se - em todos os campos nos quais a lei pode se impor como lei. A lei da literatura tende, em princípio, a desafiar ou a suspender a lei ${ }^{24}$.

Para permanecermos na utilização do próprio vocabulário derridiano, façamos uma rasura sobre a palavra literatura, ali posicionada no texto do filósofo francês. Ao seu lado, tomemos a liberdade de inscrever a palavra arte, buscando suplementar o alcance da potência teórica pelo alargamento do campo ao qual ela se refere.

É neste diapasão que procuro o encontro com o texto artístico, em sentido amplo, aqui. Trata-se de uma elaboração do dizer que, independentemente da linguagem em que se apresenta, não raro procura o escape em relação aos condicionamentos que vigiam, limitam e punem o ato enunciativo. Deste modo, a arte produz aberturas, ainda que pequenas brechas, quando todo o seu entorno reza por fechamentos - furos no cano por onde se estabelecem linhas de fuga, no dizer de Gilles Deleuze ${ }^{25}$. Organiza, neste entre-lugar do apesar de tudo, pequenas traições à lógica hegemônica: espaços de respiro, afirmações de vida, resistências que se organizam desde a invenção de um povo menor, que falta ${ }^{26}$. A arte guarda em si o gérmen da indocilidade, tal como se vê em Língua apunhalada, intervenção fotográfica de Lygia Pape, em pleno ano de 1968, quando do recrudescimento da ditadura militar brasileira em virtude do Ato Institucional $n^{\circ} 5$, que vinha sendo preparado desde julho:

\footnotetext{
24 Jacques Derrida, Esta estranha instituição chamada literatura, 2014, p. 49.

${ }^{25}$ Gilles Deleuze e Claire Parnet, Diálogos, 1998.

${ }^{26}$ Gilles Deleuze, A literatura e a vida, 2011.
} 


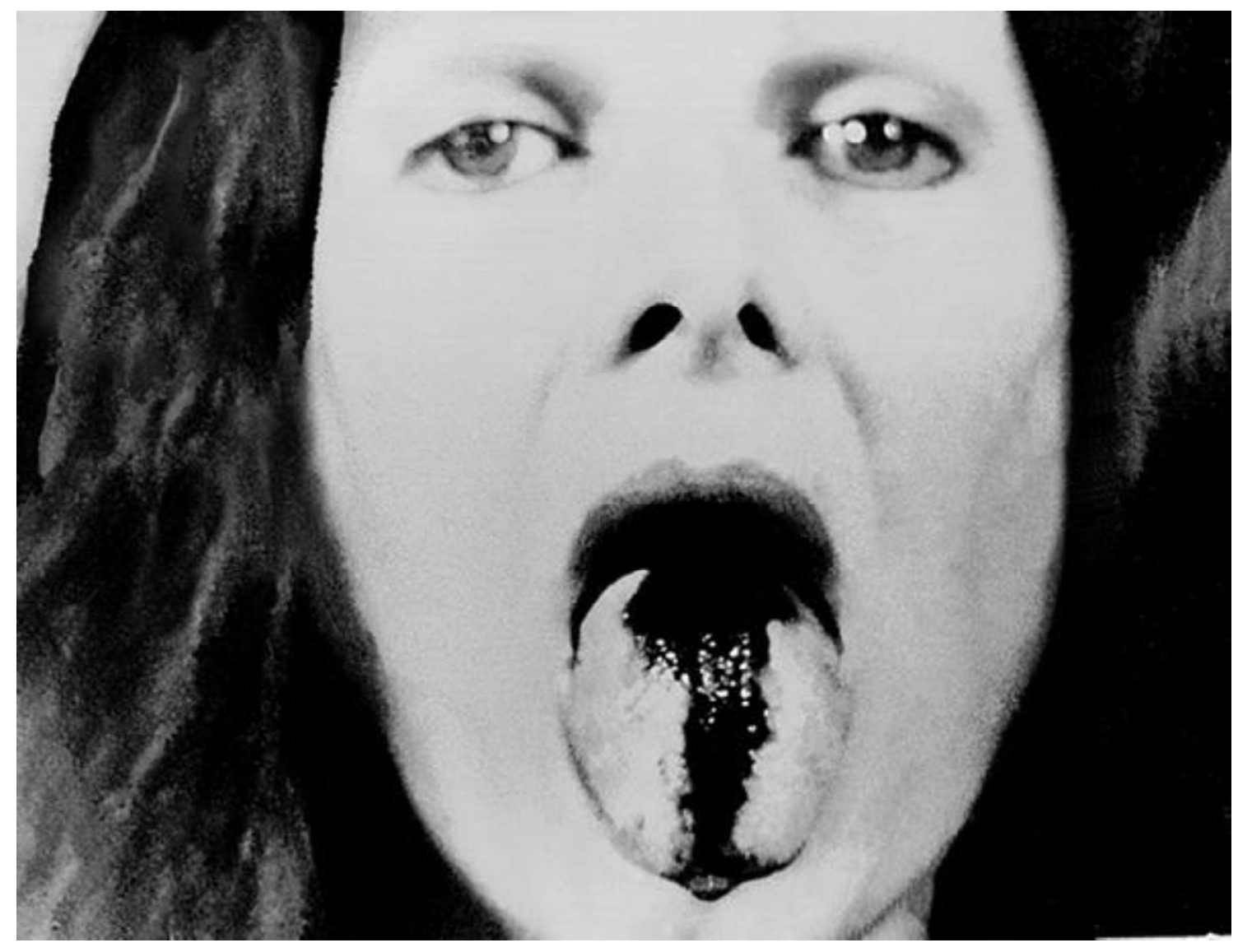

Figura 1

Lygia Pape, Língua apunhalada, 1968.

A lei era o silêncio: bocas caladas, amordaçadas; palavras medidas, minuciosamente calculadas ou riscadas sob a tinta e a autoridade de algum censor. Faltavam palavras, pode até ser verdade, mas não o dizer. A artista fotografa a si mesma em close-up, o rosto um pouco deslocado para a direita em relação ao centro da imagem já coloca em cena a produção de um desvio. Sua expressão carrega alguma inquietante serenidade: não há uma contração de músculo, um apertar de olhos. A direção de seu olhar alinha-se ao do público, e é também quase sem vida. A pálpebra direita encontra-se levemente suspensa, como se indecisa entre o movimento de se fechar ou de se abrir. Tal arquitetura, no entanto, contrasta com a boca: decididamente aberta, potentemente aberta, obscenamente aberta. Aqui, para usar a metáfora de Georges Didi-Huberman, a 
imagem "[...] arde por sua audácia, quando faz com que todo retrocesso, toda retirada sejam impossíveis" ${ }^{27}$. Arder: provocar um incêndio em seu encontro com o real, tal é a força das imagens, para Didi-Huberman ${ }^{28}$. Não se trata de representar mimeticamente o real, mas de provocá-lo, de fazê-lo acender-se sob chamas que desconcertam mais do que queimam; que tensionam mais do que destroem. A boca, esta cavidade que a ditadura quis extirpar do corpo humano, expulsando-a para o fora da cena, reaparece aqui como local de convergência desta imagem. Se a querem fechada, ela se abre tanto quanto pode. $E$ faz questão de não esconder a língua - a língua-músculo, parte de nossa composição anatômica, mas também a língua-fala, a partir da qual os nossos dizeres, inclusive os de revolta e de luta, se colocam. Ela salta da boca e se exibe: apunhalada, é verdade; sangrando, é verdade, mas, ainda assim, dizendo; mas, ainda assim, intervindo. Talvez ela até cante, com Chico Buarque e Gilberto Gil: "Pai / afasta de mim esse cálice / de vinho tinto de sangue"29 - embora a artista não pareça precisar da intervenção de nenhum pai: ela esbanja força, ela é força. Em todo caso, a arte pode inclusive cantar, quando a ordem é o silêncio.

Onde as palavras são caçadas, as imagens continuam a dizer: a arte sempre encontra o seu jeito. Mesmo no espaço mínimo do apesar de, ou exatamente por causa dele, a arte pode. Em 1975, Letícia Parente produz, em vídeo, a performance Marca Registrada (Figura 2).

A boca já não diz, mas o pé descalço: este nosso modo mais imediato de contato com um chão - também aquele de barro ou de cimento, de areia ou de madeira, mas, sobretudo, em uma perspectiva simbólica, um chão que é território, ao qual se pertence, constituindo, desse modo, a tessitura microfísica de nossas relações sociais. É, pois, do contato íntimo com o solo brasileiro que Letícia Parente tem o seu corpo marcado.

\footnotetext{
${ }^{27}$ Georges Didi-Huberman, Quando as imagens tocam o real, 2012, p. 216.

${ }^{28}$ Ibidem.

${ }^{29}$ Chico Buarque de Holanda e Gilberto Gil, Cálice, 1978.
} 


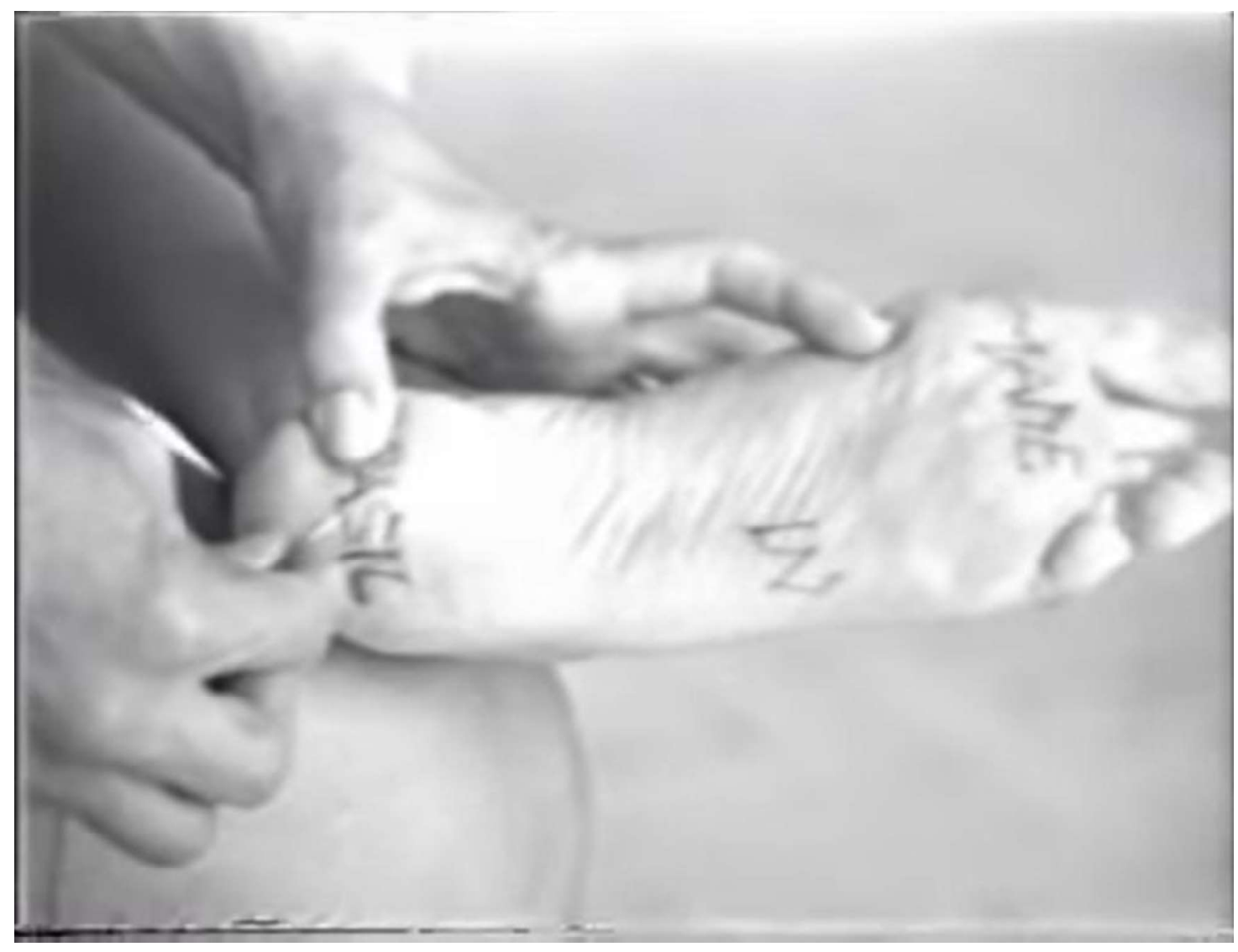

Figura 2

Letícia Parente, Marca registrada, 1975

Diferentemente de Lygia Pape, que se insere no contexto de instauração do AI-5, Parente encontra-se já em seus anos finais. Com isso, a performance que ela executa aciona, por meio da produção de dor em seu próprio corpo, a memória de dor que a ditadura militar, então em curso, vinha provocando. A artista costura em seu pé esquerdo a expressão made in Brasil, com a qual registra a procedência daquela experiência dolorosa. Os corpos dilacerados pelo regime, desaparecidos sob o chão cúmplice e silencioso deste nosso país, comunicam-se conosco pelas linhas costuradas naquele pé: lembrar estas marcas registradas da ditadura: a aflição e a dor.

Às vezes, o poder da máquina repressora é demasiado. Às vezes, o peso sobre nossas costas é desumano. Às vezes, como no momento em que Pape e 
Parente produzem, tudo parece sem saída, tudo parece uma grande e triste derrota. Às vezes, parece mesmo que não se trata de o inimigo continuar vencendo, mas de este ser um jogo em que somente ele pode vencer. Às vezes, render-se ao fatalismo parece ser a atitude mais honesta possível - talvez, inevitável. No entanto, é mesmo em face destas possíveis frustrações que se torna necessário dar as mãos a Georges Didi-Huberman, que ensina:

[...] uma coisa é designar a máquina totalitária, outra coisa é lhe atribuir tão rapidamente uma vitória definitiva e sem partilha. Assujeitou-se o mundo, assim, totalmente como o sonharam - o projetam, o programam e quem no-lo impor - nossos atuais "conselheiros pérfidos"? Postulá-lo é, justamente, dar crédito ao que sua máquina quer nos fazer crer. É ver somente a noite escura ou a ofuscante luz dos projetores. É agir como vencidos: é estarmos convencidos de que a máquina cumpre seu trabalho sem resto nem resistência. É não ver mais nada. É, portanto, não ver o espaço - seja ele intersticial, intermitente, nômade, situado no improvável - das aberturas, dos possíveis, dos lampejos, dos apesar de tudo ${ }^{30}$.

Não é coincidência que um dos principais esforços organizados na perspectiva de um assujeitamento do mundo seja a tentativa de exercer um controle sobre as artes. Não à toa, Platão quis expulsar os poetas - estes seres produtores de desvios - de sua República ${ }^{31}$. Não à toa, durante a Idade Média, a Igreja Católica tentou conter e delimitar o que poderia e o que não poderia ser veiculado como arte. Não à toa, os regimes totalitários do século XX desenvolveram seus próprios modelos estéticos, conjuraram todos os demais. Por exemplo, Hitler e sua posição sobre a arte moderna, entendida como degenerada e, portanto, de influência maléfica sobre a população: artistas e professorxs presxs, mortxs. Do outro lado do espectro político, sob o regime de Stálin, Andrei Zhdanov fixou e defendeu a estética do realismo soviético. Artistas e professorxs não alinhadxs a este padrão também presxs e mortxs. Nos paranoicos Estados Unidos do senador Joseph McCarthy, qualquer produção artística que pusesse em tensão o modo de vida estadunidense e as maravilhas do capitalismo era censurada sob a acusação de propaganda comunista: mesmo Charlie Chaplin precisou sair do país, em 1952, para conseguir respirar e continuar produzindo.

\footnotetext{
${ }^{30}$ Georges Didi-Huberman, Sobrevivência dos vaga-lumes, 2011, p. 42.

${ }^{31}$ Platão, República, 2002.
} 
No Brasil, que passou por duas ditaduras no século passado, é sem conta o número de artistas cooptadxs, censuradxs, exiladxs, presxs, torturadxs. No Brasil de hoje, 2019, há uma investida em curso de estrangulamento de toda e qualquer manifestação artística contrária ao governo instituído ou que parta de outros lugares ideológicos que não aqueles que tomaram de assalto o Palácio do Planalto.

O painel é triste, sem dúvida, mas dele se tira uma importante lição: os governos estabelecidos, todos eles, quanto mais poderosos o são, mais reconhecem na arte uma potência para desestabilizá-los, para fissurá-los desde dentro. Quanto mais investem em estratégias de silenciamento, mais sabem que a arte não se deixa silenciar: ela, como a mosca daquela música do Raul Seixas, é rizomática: "E não adianta / vir me dedetizar / pois nem o DDT / pode assim me exterminar / porque cê mata uma / e vem outra em meu lugar"32.

Não há nenhum processo de opressão que não gere movimentos de resistência em resposta. E a arte, como espaço propício à suspensão de todas as leis, é não apenas veículo destas manifestações: sobretudo, ela é a potência do desejo de emancipação que se encarna em linguagem. Por esta razão, Silviano Santiago demarca que o pensamento de Didi-Huberman "....] pretende organizar o pessimismo moderno e sustentar um espaço de imagens artísticas contraideológicas e subjetivas que visam minar a fúria atual das pressões obscurantistas" ${ }^{\prime 3}$. Encontrar-se com tais artistas, então, abraçá-lxs e ser por elxs abraçadx, constituir uma zona de afecção entre público e obra: aí, neste lugar de trânsito, a arte transmite a sua força de vida a quem vive em meio à morte. De fato, para Didi-Huberman, as obras de arte, assim como as pessoas, podem ser vaga-lumes, o que significa dizer que elas têm a possibilidade de estabelecer uma espécie de relação desviante e crítica no que concerne à sociedade na qual se inserem ${ }^{34}$.

\footnotetext{
${ }^{32}$ Raul Seixas, Mosca na sopa, 1973.

${ }^{33}$ Silviano Santiago, Uma revoada de vagalumes, 2017.

${ }^{34}$ Georges Didi-Huberman, Luz contra luz, 2015.
} 
O poeta, cineasta e ensaísta italiano Pier Paolo Pasolini, já próximo ao fim trágico de sua vida, acreditava que o fascismo havia triunfado e se apresentava, nas décadas de 1960 e 1970, muito mais terrível do que durante o regime de Mussolini. Para ele, os meios através dos quais o modo de vida dominante se expandia, buscando a captura dos desejos e a padronização dos sujeitos, havia desestruturado, irremediavelmente, as formas-desvio situadas desde o fora dos lugares de hegemonia: as classes populares. Neste cenário, as luzes múltiplas e delicadas dos pequenos vaga-lumes, metáfora formulada décadas antes para comunicar uma potência errática e não-redutível à ordem instituída, havia sido ofuscada pela grande luz emitida por holofotes, projetores e aparelhos televisivos a partir dos quais se executava um projeto de homogeneização cultural. Os vagalumes, para Pasolini, estavam extintos.

Georges Didi-Huberman retoma Pasolini, mas em diferença. Em Sobrevivência dos vaga-lumes, ele argumenta que por mais avançados, diversos e poderosos que sejam os maquinismos totalitários utilizados para a produção de capturas, de silenciamentos e de extermínios, há sempre algo que, justamente por sua pequeneza, consegue escapar. Pequenos vaga-lumes, cujos lampejos mínimos acenam com a possibilidade de formas outras de vida que não aquelas autorizadas e legitimadas pela ordem imperante. Formas sobreviventes. Formas rasurantes. A parca luminescência destes seres, tão frágil que sequer agride aos olhos, é inversa à capacidade que detêm de resistir ou de produzir sins a uma vida plural e aberta a todos os fluxos e desvios. Localizá-los exige um modo outro de ver, uma outra política de luzes, não rendida à sedução daquela que se apresenta como grande e única. Trata-se de olhar em ou através de espaços intersticiais, situados no improvável; ver por meio de frestas abertas pela insubordinação de um artista como Cildo Meireles, que assina, nos anos de 1970 e 1971, a série Inserções em circuitos ideológicos - Projeto Coca-Cola 


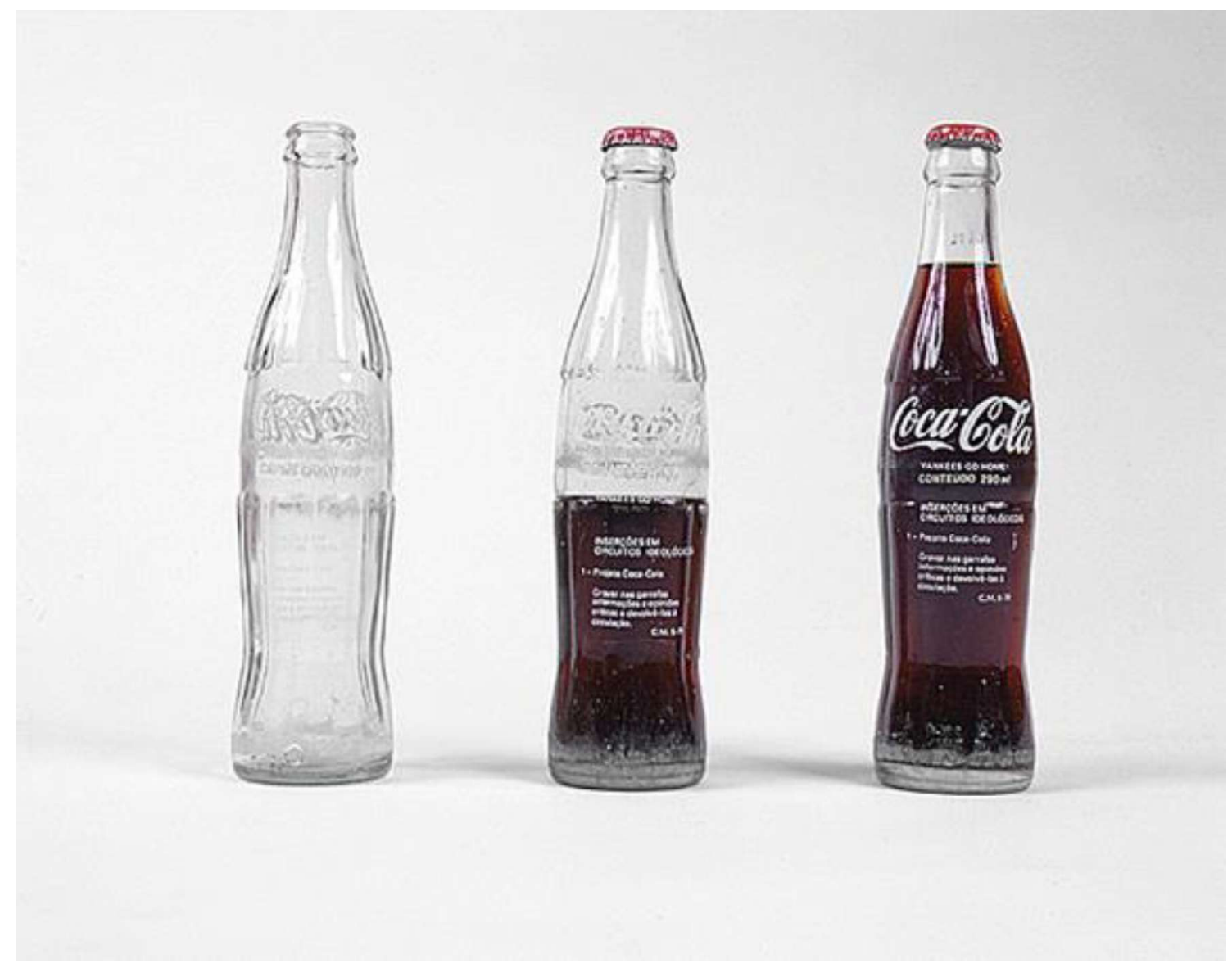

Figura 3

Cildo Meireles, Inserções em circuitos ideológicos - 2. Projeto Coca-Cola, 1971.

Técnica de silk screen sobre garrafas retornáveis de Coca-cola. Mensagens contra o imperialismo americano, ironicamente dispostas sobre o produto que, talvez, mais o simbolize. Ensinamentos de técnicas de combate, como, por exemplo, utilizar-se daquela mesma garrafa para fabricar um coquetel molotov - bomba rudimentar, feita com um recipiente de vidro, algum líquido inflamável e um pedaço de pano, que espalha chamas e cacos perfuro-cortantes ao explodir.

Talvez não tenha havido um investimento de metalinguagem na concepção destas intervenções artísticas, mas pensá-las sob esta clave parece-me fértil. O período corresponde ao auge da ditadura militar, ao seu momento mais tenso e violento, quando, acuados e sem outras alternativas, os movimentos de resistência se armam e as guerrilhas urbanas e campesinas eclodem em todo o 
território nacional. Neste sentido, Cildo Meireles não apenas ensina a produzir um coquetel molotov, ele de fato assemelha a arte a esta condição incendiária, tomando-a como arma contra seu tempo. O ensinar a fazer, o dizer como, transforma-se na própria coisa: a arma já está pronta para provocar incêndios com suas labaredas de palavras explodindo contra silêncios.

Nenhum coquetel molotov, bem o sabemos, é capaz de vencer uma guerra: seu alcance é curto, seu raio de ação é mínimo. No entanto, se pensado menos como o artefato a que se refere e mais como uma aproximação à própria ação artística, há algo de força nesta criação que sobrevive ainda hoje, comunicandonos a possibilidade de um levante. E levantar-se, ainda segundo Didi-Huberman,

[...] é jogar longe o fardo que pesava sobre nossos ombros e entravava o movimento. É quebrar certo presente [...] e erguer os braços ao futuro que se abre. É um sinal de esperança e de resistência. É um gesto e uma emoção. [...] No gesto do levante, cada corpo protesta por meio de todos os seus membros, cada boca se abre e exclama o não da recusa e o sim do desejo ${ }^{35}$.

O não da recusa; o sim do desejo: a arte.

O que pode, portanto, a arte?

Desafiar as leis, dizer o impossível de ser dito, incendiar, tal um molotov, os poderes instituídos, produzir desvios: desde sempre, desde os inícios. Reverberar como força de (ou como força para) em quem estabelece encontros fortes com ela.

Em 1964, poucos dias após o golpe militar e a publicação, em 9 de abril, do Ato Institucional Número 1, que visava dar legitimidade e sustentação ao regime dos generais, além de colocar em suspenso a Constituição e, com isso, suas garantias, o poeta Thiago de Mello escreveu Os Estatutos do Homem (Ato Institucional Permanente), até hoje o seu texto mais conhecido. Formulado à semelhança de um código de leis, estética adotada para desestabilizar a legislação oficial, o texto desmonta, por contraste, o AI-1: onde este suprime liberdades, o

${ }^{35}$ Georges Didi-Huberman, Levantes, 2017, p. 117. 
poeta as instaura. No código estabelecido por Thiago de Mello, à revelia do ímpeto dos generais para reprimir e silenciar, lê-se, em seu artigo final:

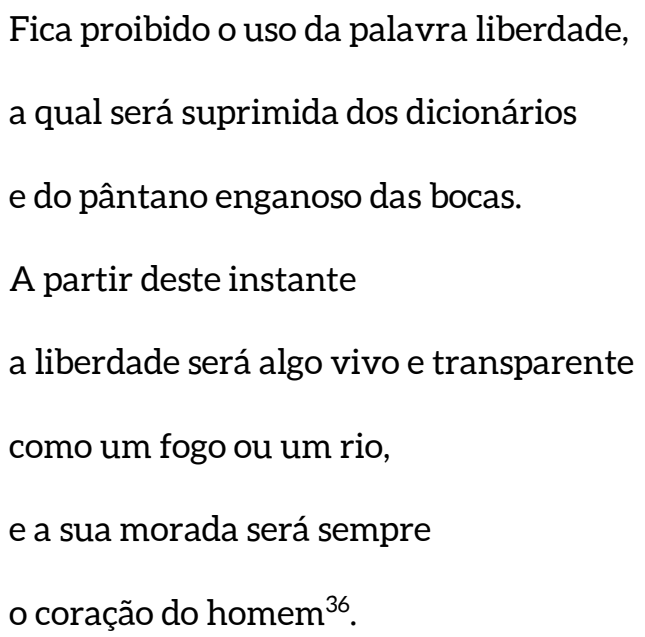

A proibição da palavra liberdade alude às restrições impostas às liberdades civis articuladas pela máquina ditatorial. A referência, no entanto, não se faz no nível de uma concordância. Ao invés disso, tensiona o regime negando-lhe o uso da palavra na medida em que a exerce, em sua plenitude, na própria dinâmica da vida, uma vez que posicionada no coração dos homens, não no pântano enganoso das bocas silenciadas.

No ano seguinte, 1965, este poema foi reunido a outros e publicado em livro intitulado Faz escuro, mas eu canto - fórmula lapidar. A adversativa mas desvela a relação tensa que se coloca entre o poeta e o seu tempo. O termo "faz escuro" remete ao presente, tempo sombrio em que o poeta se situa, algo que lhe é externo mas que, como noite, o envolve em sua escuridão. "Eu canto", por sua vez, direciona um agir de não alinhamento ao instante vivido, uma postura de inconformidade e de desafio lançado à ordem dominante. Reversão do interdito: onde o regime impõe o silêncio e pune a crítica, a arte transpõe, diz o que não pode. Devém o veto em liberdade de dizer.

${ }^{36}$ Thiago de Mello, Os estatutos do homem (ato institucional permanente) (1964), 1978. 
Quantos outros acenos de força eu poderia aqui abraçar, no espaço que ainda tenho? São tantos que me vêm aleatoriamente à memória... Um Geraldo Vandré menos conhecido, talvez. Pra não dizer que não falei das flores é canção até hoje entoada em manifestações Brasil afora, mas os versos de Porta-estandarte, que sempre me impactam mais, definem melhor a proposta $\mathrm{dx}$ artista:

\author{
Eu vou levando a minha vida enfim \\ cantando e canto sim \\ e não cantava se não fosse assim \\ levando pra quem me ouvir \\ certezas e esperanças pra trocar \\ por dores e tristezas que bem sei \\ um dia ainda vão findar \\ um dia que vem vindo e que eu vivo pra cantar ${ }^{37}$.
}

Talvez aquela música de Maurício Tapajós e Paulo César Pinheiro, gravada pelo MPB-4 em Cicatrizes, disco de 1972. Produzida quando a sociedade estava submetida ao Ato Institucional $\mathrm{n}^{\circ} 5$, ela é, de modo ambíguo, intitulada "Pesadelo". Refere-se, sem dúvida, à angústia dos anos de chumbo que compõe a experiência do eu-lírico, mas estende-se para abranger também, e principalmente, os generais. O eu-lírico não deseja comunicar o pesadelo em que vive, mas a si próprio como um pesadelo que atormenta a estrutura repressiva montada pelo regime: "Você corta um verso, eu escrevo outro / você me prende vivo, eu escapo morto / de repente, olha eu de novo / perturbando a paz, exigindo troco"38.

\footnotetext{
${ }^{37}$ Geraldo Vandré, Porta-estandarte (1966), 1979

${ }^{38}$ Maurício Tapajós e Paulo César Pinheiro, Pesadelo, 1972.
} 
Escrever/cantar como ato de resistência, como produção de sobrevivência. O uruguaio Mario Benedetti, censurado e expulso de várias ditaduras na América Latina, resume bem:

cantamos pela infância e porque tudo
e porque algum futuro e porque o povo
cantamos porque os sobreviventes
e nossos mortos querem que cantemos

cantamos porque o grito só não basta

e já não basta o pranto nem a raiva

cantamos porque cremos nesta gente

e porque venceremos a derrota

cantamos porque o sol nos reconhece

e porque o campo cheira a primavera

e porque neste talo e lá no fruto

cada pergunta tem a sua resposta

cantamos porque chove sobre o sulco

e somos militantes desta vida

e porque não podemos nem queremos

deixar que a canção se torne $\operatorname{cinzas}^{39}$.

Assim como nos outros encontros, também aqui o poeta é confrontado pela realidade dura de seu tempo, descrito como um "covil de ladrões" no qual "cada hora vem com a sua morte"; um tempo em que "a pátria está morrendo de

\footnotetext{
${ }^{39}$ Mario Benedetti, Por que cantamos (1979), 1988, p. 145
} 
tristeza" e que, em cada noite e em cada despertar, experimentam-se apenas ausências e desencontros - xs mortxs e desaparecidxs políticxs se multiplicavam em toda a América Latina. Neste cenário, uma pergunta se coloca: por que cantamos? E a resposta: justamente por causa deste tempo e das interdições de vida que ele acarreta. Ou melhor, canta-se contra este tempo-noite, este tempochumbo, este tempo-obscuro que o poeta experimenta e ao qual resiste, comunicando a quem o lê uma força para estar ainda aqui.

Do mesmo modo procede a escritora Lygia Fagundes Telles, em As meninas. O ano era 1972 e ali, naquele romance, a literatura fazia o trabalho que a imprensa estava impedida de fazer: expor as cenas de tortura pelas quais passavam milhares de pessoas nos porões dos aparelhos de repressão do Estado:

Quero que ouça o trecho do depoimento de um botânico perante a justiça, ele ousou distribuir panfletos numa fábrica. Foi preso e levado à caserna policial, ouça aqui o que ele diz, não vou ler tudo: Ali interrogaram-me durante vinte e cinco horas enquanto gritavam, traidor da pátria, traidor! Nada me foi dado para comer ou beber durante esse tempo. Carregaramme em seguida para a chamada capela: a câmara de torturas. Iniciou-se ali um cerimonial frequentemente repetido e que durava de três a seis horas cada sessão. Primeiro me perguntaram se eu pertencia a algum grupo político. Neguei. Enrolaram então alguns fios em redor dos meus dedos, iniciando-se a tortura elétrica: deram-me choques inicialmente fracos que foram se tornando cada vez mais fortes. Depois, obrigaram-me a tirar a roupa, fiquei nu e desprotegido. Primeiro me bateram com as mãos e em seguida com cassetetes, principalmente nas mãos. Molharam-me todo, para que os choques elétricos tivessem mais efeito. Pensei que fosse então morrer. Mas resistia e resisti também às surras que me abriram um talho fundo em meu cotovelo. Na ferida o sargento Simões e o cabo Passos enfiaram um fio. Obrigaram-me a então a aplicar os choques em mim mesmo e em meus amigos. Para que eu não gritasse enfiaram um sapato dentro da minha boca. Outras vezes, panos fedidos. Após algumas horas, a cerimônia atingiu seu ápice. Penduraram-me no pau-de-arara: amarraram minhas mãos diante dos joelhos, atrás dos quais enfiaram uma vara, cujas pontas eram colocadas em mesas. Fiquei pairando no ar. Enfiaram-me então um fio no reto e fixaram outros fios na boca, nas orelhas e mãos. Nos dias seguintes o processo se repetiu com maior duração e violência. Os tapas que me davam eram tão fortes que julguei que tivessem me rompido os tímpanos: mal ouvia. Meus punhos estavam ralados devido às algemas, minhas mãos e partes genitais completamente enegrecidas devido às queimaduras elétricas ${ }^{40}$.

${ }^{40}$ Lygia Fagundes Telles, As meninas (1972), 1985. 
Em litígio com o seu tempo, a arte pode ser o contraponto necessário para que nem tudo seja derrota e dor. Para que nem tudo seja silêncio. A arte pode, não porque para ela seja emitida uma concessão exclusiva, privando-a dos condicionamentos dos quais a sociedade civil se encontra cativa. Não. A arte pode porque ela é força imparável. Como diz Caetano Veloso, naquela canção sobre o ofício de artista: "por isso uma força / me leva a cantar / por isso essa força / estranha no ar / por isso é que eu canto / não posso parar / por isso essa voz tamanha"41 - a arte é uma força que, quando tudo é proibição, grita, propositadamente desafinada, enfrentando uma plateia hostil, ainda por intermédio de Caetano, "e eu digo não! / e eu digo não ao não / eu digo: / é proibido proibir"42.

"Eu vi muitos cabelos brancos / na fronte do artista / o tempo não para / e, no entanto, / ele nunca envelhece" 43 . O corpo, evidentemente, obedece às leis naturais que determinam o envelhecimento e a morte. Sim, o tempo passa para o corpo dx artista. Mas x artista está mais em sua arte do que em seu corpo - ou melhor, está mais nos encontros que sua arte produz junto a outros corpos. E, nesse sentido, elx pode não envelhecer, elx pode não morrer. X artista, já o demonstrou Giorgio Agamben, pode se apresentar como contemporâneo, de modo que o branco dos cabelos não indica nenhuma velhice ${ }^{44}$.

Para o filósofo italiano, o contemporâneo, ao invés de se relacionar à ideia de "atual", solicita uma espécie de deslocamento que o constitui como inatual. Não é o caso, com isso, de imaginar uma atitude melancólica, dobrada sobre a ausência do que se perdeu, ou escapista, idealizadora do que não se viveu. Tais são comportamentos estéreis sob o ângulo de uma intervenção crítica e pontual no presente. O contemporâneo, ao contrário, é uma fratura em relação ao seu presente, pois a ele não adere e nem o reproduz.

\footnotetext{
${ }^{41}$ Caetano Veloso, Força Estranha, 1978.

${ }^{42}$ Caetano Veloso, É Proibido proibir, 1968.

${ }^{43}$ Caetano Veloso, Força Estranha, 1978.

${ }^{44}$ Giorgio Agamben, O que é o contemporâneo?, 2009.
} 
Ainda seguindo o pensamento de Agamben, para quem experimenta o tempo na condição de um contemporâneo, dele não tem outra percepção senão a de uma inevitável obscuridade. Trata-se de não coincidir totalmente com o período em que se vive e, por isso, receber seu facho de trevas em pleno rosto: no mais além de um fascínio pelas luzes, a coragem de encarar o escuro, descobrir o sombrio. O contemporâneo é uma quebra na continuidade do status quo, cujas luzes cegam, por captura.vigilância.punição, outros modos possíveis de vida, de resto interditados. Ao agir em seu tempo e contra o seu tempo, independentemente do período histórico em que esteja, $\mathrm{x}$ artista atento às demandas do contemporâneo promove aberturas, alquimia modos outros de existir no mundo.

A arte, como um espaço de agência do contemporâneo em que se pode dizer tudo, comporta discursos menores, para dialogar com Deleuze e Guattari, que a partir deles situam a possibilidade de um devir-outro, um coeficiente de desterritorialização de toda hegemonia ${ }^{45}$. Ou, simplesmente, vidas vaga-lumes como aquelas cantadas pela Estação Primeira de Mangueira, a Verde-e-rosa do Rio de Janeiro, em seu samba-enredo deste ano, 2019, intitulado História para ninar gente grande:

\author{
Brasil, meu nego, deixa eu te contar \\ a história que a história não conta \\ o avesso do mesmo lugar \\ na luta é que a gente se encontra \\ $[\ldots]$ \\ Salve os caboclos de julho \\ quem foi de aço nos anos de chumbo \\ Brasil, chegou a vez \\ de ouvir as Marias, Mahins, Marielles, malês ${ }^{46}$.
}

\footnotetext{
${ }^{45}$ Gilles Deleuze e Felix Guattari, Kafka: para uma literatura menor, 2003.

${ }^{46}$ Deived Domênico, Tomaz Miranda, Mama, Márcio Bola, Roniê Oliveira e Danilo Firmino, História para ninar gente grande, samba-enredo da Estação Primeira de Mangueira, 2019.
} 


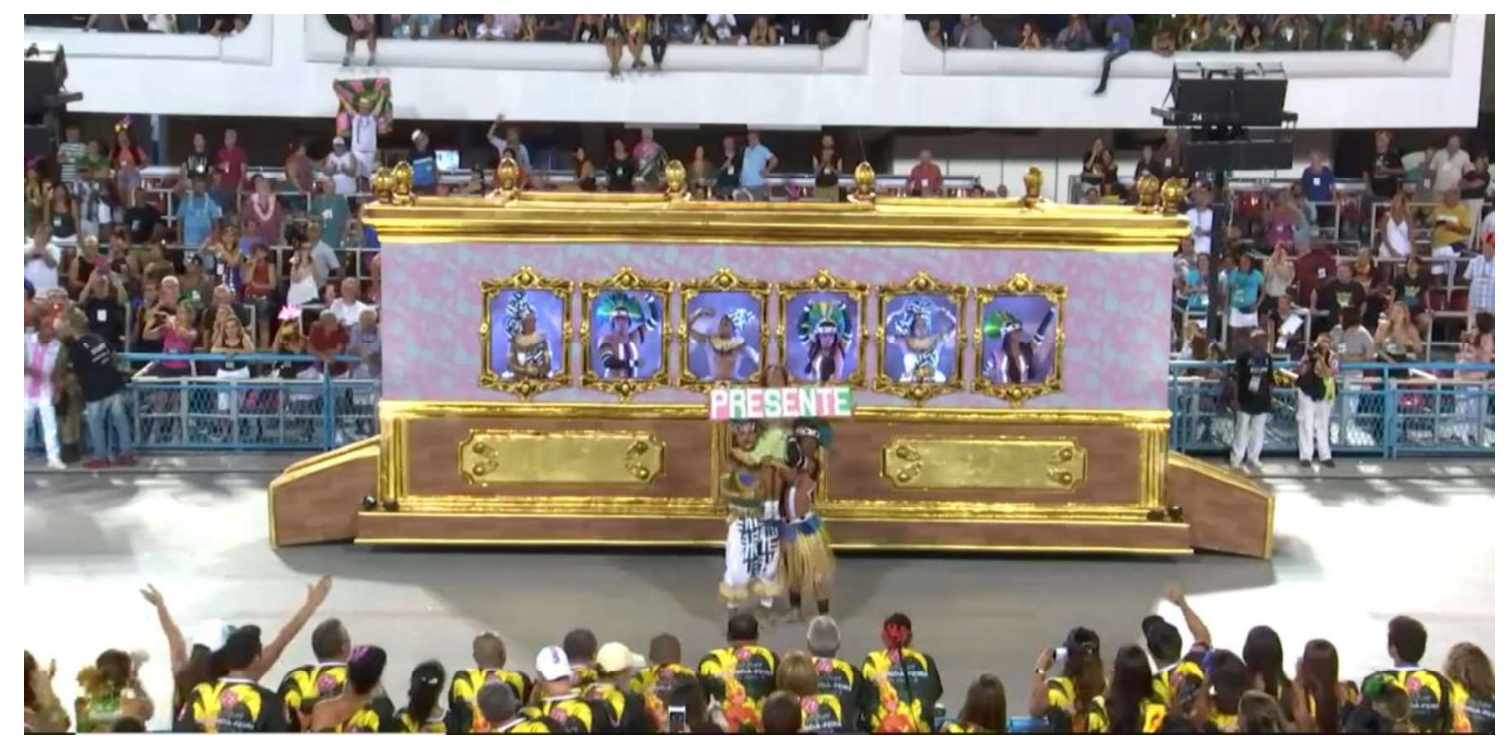

Figura 4

Comissão de Frente: "Eu quero um país que não está no retrato" Coreógrafos: Priscila Mota e Rodrigo Nery

Estação Primeira de Mangueira, 2019

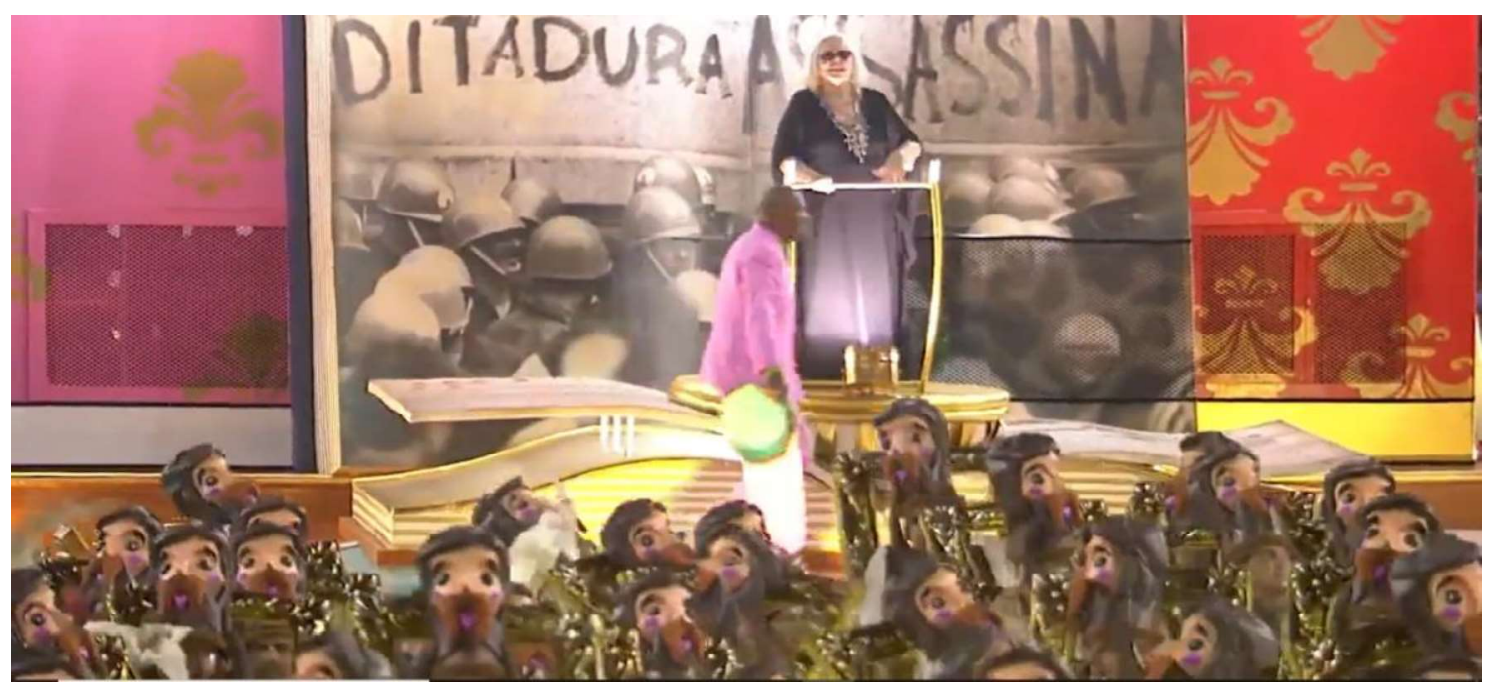

Figura 5

Carro alegórico: "A história que a história não conta"

Carnavalesco: Leandro Vieira

Estação Primeira de Mangueira, 2019 
Contra a história oficial de um Brasil de assassinatos impunes e heroicizados. Contra o silenciamento e a difamação daquelas e daqueles que deram suas vidas por uma perspectiva outra de país. Contra a produção de morte e de esquecimento. Contra o Brasil de Jair Bolsonaro e todo o retrocesso que sua figura caricata e histriônica representa. A Mangueira entrou na Marquês de Sapucaí para desfilar alegria e crítica, força e coragem. Da comissão de frente, que destrona nossos supostos heróis para exibi-los em sua flagrante e ridícula pequeneza, contrapondo-os a negras, negros e indígenas, devidamente engrandecidxs pela encenação, ao último carro alegórico, que trazia Hildergard Angel, irmã do estudante Stuart Angel, assassinado pela ditadura militar, vestida no traje de luto desenhado e utilizado por sua mãe, a estilista Zuzu Angel, inclusive com o colar de cruzes com o qual ela se apresentava perante as autoridades brasileiras, além da inscrição "ditadura assassina", quando o atual presidente nega ter havido um processo ditatorial no país, solicita a revisão histórica do período e faz homenagens públicas ao torturador e assassino Carlos Brilhante Ustra; do início ao fim, o desfile da Estação Primeira de Mangueira é uma força que nos abraça, ampara o nosso desamparo e diz: vem, canta conosco.

Se o tempo presente nos lança ao rosto seus refletores mais poderosos e, uma vez que nos desviamos deles, seu absurdo facho de trevas, é mesmo na noite escura na qual o contemporâneo nos encontra que a dança-voo dos vaga-lumes se faz presente. Os vaga-lumes não estão no quando ou onde nós não estamos. Eles estão aí e agora. Eles estão aqui e agora. Como estiveram antes. Como estarão depois. Podem estar no verso de uma música. Na boca aberta de uma fotografia. No pé costurado de uma performance em vídeo. Nas instruções para um coquetel molotov. Nos textos literários. No desfile de uma escola de samba. Eles estão. A busca por suas luzes mínimas, pelo encontro amoroso com elas, se configura como uma estratégia política de sobrevivência e luta ante estruturas de pensamento e ação social que historicamente se revelam produtoras de morte. Os vaga-lumes são necessários. E a arte está repleta destes pequenos seres erráticos e luminescentes. 
Uma última imagem, a título de encerramento. O ano era 1979 e o general João Baptista de Oliveira Figueiredo, recém-empossado no cargo político máximo da nação, fazia uma visita oficial ao estado de Minas Gerais. Toda a cena havia sido montada para demonstrar apoio popular ao militar, mas alguém esqueceu de combinar com Rachel Clemens Coelho, então uma pequena menina de cinco anos de idade. A foto, hoje clássica, é de Guinaldo Nicolaevsky:

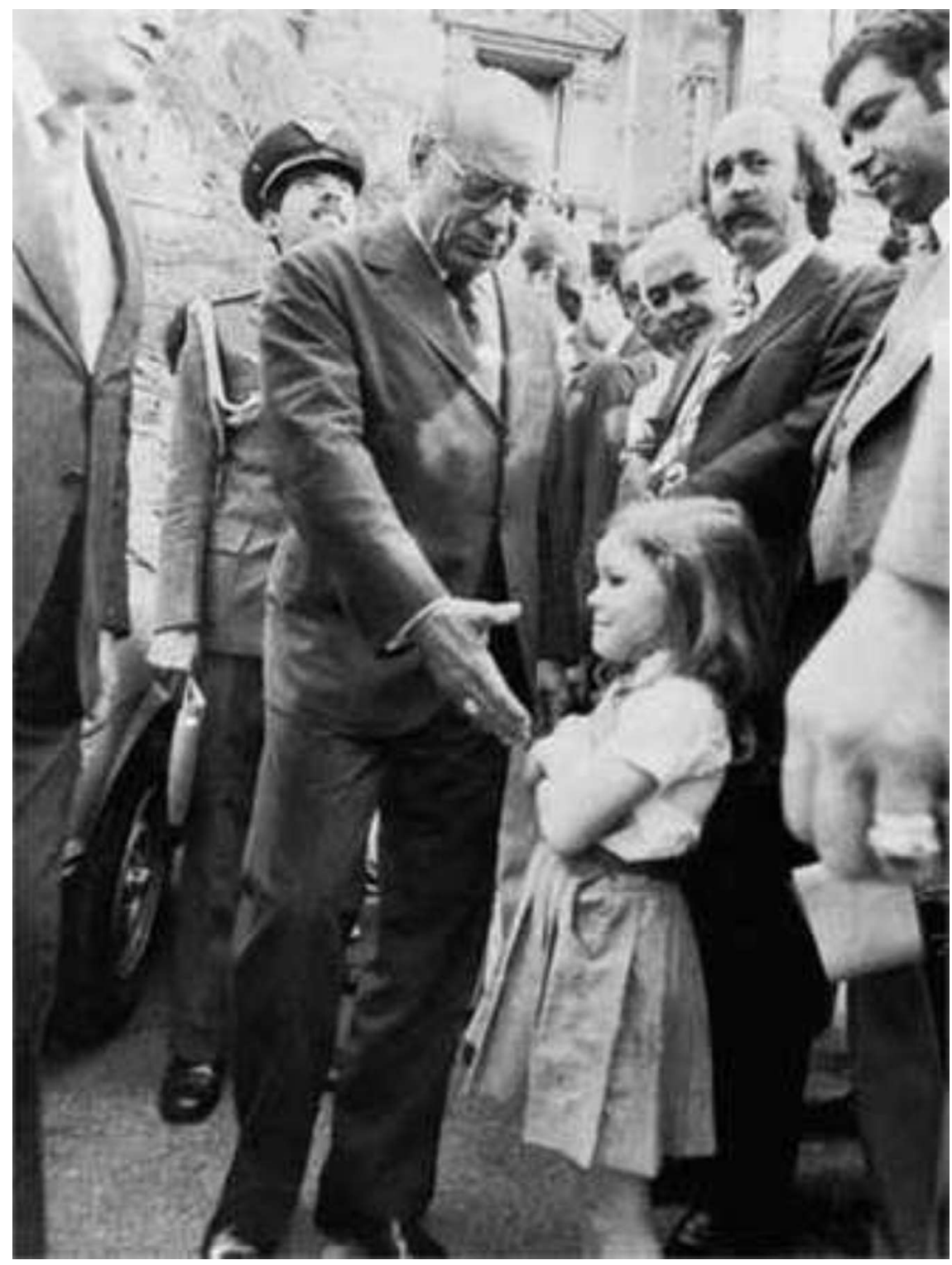

Figura 6

Guinaldo Nicolaevsky, Rachel Clemens Coelho recusa-se a cumprimentar o general Figueiredo, 1979. 
É isto: a arte é como esta menininha que sequer concede o olhar ao general Figueiredo. Ela pode ser pequena diante dos grandes aparatos bélicos de força, mas não nos esqueçamos que ser menor é uma potência: "as Minima Lumina, de que os pirilampos são a imagem exemplar, ensinam-nos que é útil ser pequeno para escapar aos poderes"47. $\mathrm{O}$ gérmen de toda indocilidade está naqueles braços cruzados diante da mão estendida. A arte, valendo-se desta fotografia, nos lembra que, não importa quão poderosa seja a máquina-noite ao nosso redor, é sempre possível que nos recusemos a lhe estender as nossas mãos; é sempre possível dizer não ao não.

\section{Um abraço}

Este texto aconteceu como uma urgência após os cinquenta e sete milhões, setecentos e noventa e sete mil, oitocentos e quarenta e sete votos predatórios computados em 28 de outubro de 2018. E permanece como uma urgência cada vez maior em face das barbaridades que se multiplicam desde janeiro de 2019.

"Há sem dúvidas motivos para ser pessimista, contudo é tão mais necessário abrir os olhos na noite, se deslocar sem descanso, voltar a procurar os vaga-lumes", afirma Didi-Huberman ${ }^{48}$. Acato o ensinamento, recebo o abraço amigo: não é sem razão que este pequeno inventário vaga-lume, aqui reunido meio que aleatoriamente, tendo por único critério as vias incertas da memória afetiva, refere-se a textualidades produzidas em momentos de violação sistemática da dignidade humana, períodos de noite densa, quase intransponível. Como diz Jorge Amado, "deve-se reconhecer que nenhuma palavra pronunciada contra a violência e a tirania é vã e inútil: alguém ao ouvi-la pode superar o medo e iniciar a resistência"49.

\footnotetext{
${ }^{47}$ Georges Didi-Huberman, Luz contra Luz, 2015, s.p.

${ }^{48}$ Georges Didi-Huberman, Sobrevivência dos vaga-lumes, 2011, p. 49.

${ }^{49}$ Jorge Amado, O sumiço da santa (1988), 2010, p. 62.
} 
Não sei termino este texto com menos angústia do que quando o iniciei, mas, sem dúvida, saio livre do sentimento de derrota. Há vaga-lumes piscando suas potências em todos os lugares, em todos os tempos. Basta que desviemos os nossos olhares dos holofotes, enfrentemos a escuridão. Não importa quantos milhões sejam os homens-noite, "amanhã vai ser outro dia"50.

Sim, sobreviveremos.

Apesar de tudo, sobreviveremos.

\section{Referências}

AGAMBEN, Giorgio. O que é o contemporâneo? In: AGAMBEN, Giorgio. O que é o contemporâneo? e outros ensaios. Tradução de Vinícius Nicastro Honesko. Chapecó: Argos, 2009.

AMADO, Jorge. O sumiço da santa. São Paulo: Companhia das Letras, 2010.

ANDRADE, Carlos Drummond de. A noite dissolve os homens (1940). In: ANDRADE, Carlos Drummond de. Sentimento do mundo. São Paulo: Companhia das Letras, 2012.

APPADURAI, Arjun. O medo ao pequeno número. In: APPADURAI, Arjun. $O$ medo ao pequeno número: ensaio sobre a geografia da raiva. Tradução de Ana Goldberger. São Paulo: Iluminuras/Itaú Cultural, 2009.

BELCHIOR. Como nossos pais. In: BELCHIOR. Alucinação. São Paulo: Polygram, 1976. 1LP (37min:25seg). Faixa A3 (4min:41seg).

BENEDETTI, Mario. Por que cantamos (1979). In: BENEDETTI, Mario. Antologia poética. Tradução de Julio Luis Gehlen. Rio de Janeiro: Record, 1988.

${ }^{50}$ Chico Buarque, Apesar de você, 1978. 
BENJAMIN, Walter. Sobre o conceito da história (1940). In: . Obras escolhidas. Volume 1. Magia e técnica, arte e política. Ensaios sobre literatura e história da cultura. Tradução de Sérgio Paulo Rouanet. 8.ed. São Paulo: Brasiliense, 2012. BOSCO, João e BLANC, Aldir. O bêbado e a equilibrista. In: BOSCO, João. Linha de passe. São Paulo: RCA, 1979. 1LP (33min:43seg). Faixa B1 (3min:22seg).

CHAUÍ, Marilena. Brasil: mito fundador e sociedade autoritária (2000). São Paulo: Fundação Perseu Abramo, 2010.

DELEUZE, Gilles. A literatura e a vida. In: DELEUZE, Gilles. Crítica e clínica. 2.ed. Tradução de Peter Pál Pelbart. São Paulo: 34, 2011.

DELEUZE, Gilles e GUATTARI, Felix. Kafka: para uma literatura menor. Tradução de Rafael Godinho. Lisboa: Assírio \& Alvim, 2003.

DELEUZE, Gilles e PARNET, Claire. Diálogos. Tradução de Eloísa Araújo Ribeiro. São Paulo: Escuta, 1998.

DERRIDA, Jacques. Essa estranha instituição chamada literatura. Uma entrevista com Jacques Derrida. Tradução de Marileide Dias Esqueda. Belo Horizonte: UFMG, 2018.

DIDI-HUBERMAN, Georges. Levantes. Tradução de Edgard de Assis Carvalho et alli. São Paulo: SESC, 2017.

DIDI-HUBERMAN, Georges. Luz contra luz. Tradução de Vanessa Brito. Lisboa: KKYM, 2015.

DIDI-HUBERMAN, Georges. Quando as imagens tocam o real. Pós, Belo Horizontes, v. 2, n. 4, p. 204-209, nov. 2012.

DIDI-HUBERMAN, Georges. Sobrevivência dos vaga-lumes. Tradução de Vera Casa Nova e Márcia Arbex. Belo Horizonte: UFMG, 2012. 
ESTAÇÃO Primeira de Mangueira. História para ninar gente grande. Desfile, Rio de Janeiro, 2019.

GONZAGUINHA. Pequena Memória para um tempo sem memória. In: GONZAGUINHA. De volta ao começo. São Paulo: EMI Odeon, 1980. 1LP (44min:57seg). Faixa B2 (5min:06seg).

GUATTARI, Felix. Revolução molecular: pulsações políticas do desejo (1981). 3.ed. Tradução de Suely Rolnik. São Paulo: Brasiliense, 1985.

HOLANDA, Chico Buarque e GIL, Gilberto. Cálice. In: HOLANDA, Chico Buarque. Chico Buarque. Rio de Janeiro: Polygram/Philips, 1978. 1LP (32min:52seg). Faixa A2 (4min).

HOLANDA, Chico Buarque. Apesar de você. In: HOLANDA, Chico Buarque. Chico Buarque. Rio de Janeiro: Polygram/Philips, 1978. 1LP (32min:52seg). Faixa B6 (3min:54seg).

KLINGER, Diana. Literatura e ética: da forma para a força. Rio de Janeiro: Rocco, 2014. (Entrecríticas).

LINS, Ivan e MARTINS, Vitor. Aos nossos filhos. In: LINS, Ivan. Nos dias de hoje. São Paulo: EMI, 1978. 1LP (34min:37seg). Faixa B5 (3min:15seg).

LISPECTOR, Clarice. Mineirinho (1962). In: LISPECTOR, Clarice. Todos os contos. Rio de Janeiro: Rocco, 2016.

MEIRELES, Cildo. Inserções em Circuitos Ideológicos - 2. Projeto Coca-Cola (1971). In: Enciclopédia Itaú Cultural de Arte e Cultura Brasileiras. São Paulo: Itaú Cultural, 2019. Disponível em:

<http://enciclopedia.itaucultural.org.br/obra6310/insercoes-em-circuitosideologicos-2-projeto-coca-cola>. Acesso em: 14 abr. 2019. Verbete da Enciclopédia. 
MELLO, Thiago de. Os Estatutos do Homem (Ato Institucional Permanente) (1964). In: MELLO, Thiago de. Faz escuro, mas eu canto. 5.ed. Rio de Janeiro: Civilização Brasileira, 1978.

PAPE, Lygia. Língua apunhalada (1968). Projeto Lygia Pape. Disponível em: http://www.lygiapape.org.br/pt/obra60.php?i=11. Acesso em: 13 abr. 2019.

PARENTE, Letícia. Marca Registrada, 1975. Vídeo (10min:33seg). Disponível em: https://www.youtube.com/watch?v=J5RakZ433wA. Acesso em: 13 abr. 2019. PLATÃO. República. Tradução de Enrico Corvisieri. Rio de Janeiro: Best Seller, 2002.

ROLNIK, Suely. O inconsciente colonial-capitalístico. In: ROLNIK, Suely. Esferas da insurreição. Notas para uma vida não cafetinada. São Paulo: n-1, 2018.

SANT'ANNA, Affonso Romano de (1980). Que país é este? In: SANT'ANNA, Affonso Romano de (1980). Que país é este? Rio de Janeiro: Rocco, 1990.

SANTIAGO, Silviano. Uma revoada de vagalumes. Revista Brasileira de Literatura Comparada, Niterói, v. 19, n. 32, p. 58-61, 2017.

SEIXAS, Raul. Mosca na sopa. In: SEIXAS, Raul. Krig-Ha, Bandolo! São Paulo: Philips Records, 1973. 1LP (29min:02seg). Faixa A2 (3min:58seg).

SONTAG, Susan. Contra a interpretação. In: SONTAG, Susan. Contra a interpretação. Tradução de Ana Maria Capovilla. Porto Alegre: L\&PM, 1987.

TAPAJÓS, Maurício e PINHEIRO, Paulo César. Pesadelo. In: MPB-4. Cicatrizes. São Paulo: Philips, 1972. 1LP (38min:16seg). Faixa B2 (3min:23seg).

TELLES, Lygia Fagundes. As meninas. 16.ed. Rio de Janeiro: Nova Fronteira, 1985. 
VANDRÉ, Geraldo. Porta-estandarte (1966). In: VANDRÉ, Geraldo. Geraldo

Vandré. Rio de Janeiro: Som Maior, 1979. 1LP (44mim:25seg). Faixa A2

(2min:12seg).

VELOSO, Caetano. É proibido proibir. Intérpretes: Caetano Veloso e os

Mutantes. 1968. Disponível em:

https://www.youtube.com/watch?v=4xEz2uva_ZE. Acesso em:14 abr. 2019.

VELOSO, Caetano. Força Estranha. In: CARLOS, Roberto. Roberto Carlos. São

Paulo: Columbia Records, 1978. 1LP (41 min). Faixa B4 (3min:49seg).

\section{Referência para citação deste artigo}

SOBRINHO, Antônio. Sobre lampejos em tempos de chumbo, ou, por uma comunidade de vaga-lumes, ou, o que pode a arte?. Revista PHILIA | Filosofia, Literatura \& Arte, Porto Alegre, volume 1, número 2, p. 89 - 123, outubro de 2019. 